Review

\title{
Vanadium Redox Flow Batteries: A Review Oriented to Fluid-Dynamic Optimization
}

\author{
Iñigo Aramendia ${ }^{1, *}\left(\mathbb{D}\right.$, Unai Fernandez-Gamiz ${ }^{1}\left(\mathbb{D}\right.$, Adrian Martinez-San-Vicente ${ }^{1}$, Ekaitz Zulueta ${ }^{2}$ \\ and Jose Manuel Lopez-Guede ${ }^{2}$ (I) \\ 1 Nuclear Engineering and Fluid Mechanics Department, University of the Basque Country UPV/EHU, \\ Nieves Cano 12, 01006 Vitoria-Gasteiz, Spain; unai.fernandez@ehu.eus (U.F.-G.); \\ amartinezdesanv@ehu.eus (A.M.-S.-V.) \\ 2 Automatic Control and System Engineering Department, University of the Basque Country UPV/EHU, \\ Nieves Cano 12, 01006 Vitoria-Gasteiz, Spain; ekaitz.zulueta@ehu.eus (E.Z.); jm.lopez@ehu.eus (J.M.L.-G.) \\ * Correspondence: inigo.aramendia@ehu.eus; Tel.: +34-945-014-066
}

check for

updates

Citation: Aramendia, I.;

Fernandez-Gamiz, U.;

Martinez-San-Vicente, A.; Zulueta, E.

Lopez-Guede, J.M. Vanadium Redox Flow Batteries: A Review Oriented to Fluid-Dynamic Optimization. Energies 2021, 14, 176. https://doi. org/10.3390/en14010176

Received: 4 November 2020 Accepted: 25 December 2020 Published: 31 December 2020

Publisher's Note: MDPI stays neutral with regard to jurisdictional clai$\mathrm{ms}$ in published maps and institutional affiliations.

Copyright: (C) 2020 by the authors. Licensee MDPI, Basel, Switzerland. This article is an open access article distributed under the terms and conditions of the Creative Commons Attribution (CC BY) license (https:// creativecommons.org/licenses/by/ $4.0 /)$.

\begin{abstract}
Large-scale energy storage systems (ESS) are nowadays growing in popularity due to the increase in the energy production by renewable energy sources, which in general have a random intermittent nature. Currently, several redox flow batteries have been presented as an alternative of the classical ESS; the scalability, design flexibility and long life cycle of the vanadium redox flow battery (VRFB) have made it to stand out. In a VRFB cell, which consists of two electrodes and an ion exchange membrane, the electrolyte flows through the electrodes where the electrochemical reactions take place. Computational Fluid Dynamics (CFD) simulations are a very powerful tool to develop feasible numerical models to enhance the performance and lifetime of VRFBs. This review aims to present and discuss the numerical models developed in this field and, particularly, to analyze different types of flow fields and patterns that can be found in the literature. The numerical studies presented in this review are a helpful tool to evaluate several key parameters important to optimize the energy systems based on redox flow technologies.
\end{abstract}

Keywords: energy storage; vanadium redox flow battery; VRFB; flow battery; vanadium; flow field; CFD; numerical model

\section{Introduction}

The growing consumption of fossil fuel reserves [1], the constant increase in power demand [2] and the environmental concerning has served to focus the attention on the development of sustainable energy alternatives, particularly wind and solar, for electricity generation and, therefore, to reduce greenhouse gas emissions [3]. Nowadays we are involved in a daily global development, which is constantly increasing our requirement of energy across the world, while the Earth in its own form and its natural resources cannot follow this development anymore. With all of this in mind, we are all compelled to study the different forms of energy sources in terms of security, access, sustainability, climate change mitigation and reduction of environmental and health impacts [4]. Renewable energies like wind and solar have experienced an exponential enhancement and spreading during the last 20 years, however, the random and intermittent nature of this kind of energies makes difficult to fully take advantage of them. For that reason, large-scale energy storage systems (ESS) are growing in popularity to guarantee the suitable and appropriate utilization of these power sources [5]. To that end, battery technology emerged as a practical application due to the large-scale storage power and volume [6]. In fact, the European Commission in its 2016 Integrated SET-Plan reported that to ensure European Union competitiveness in the global battery sector, potential uses for batteries beyond e-mobility need to be exploited [7]. Figure 1 shows the installed capacity from energy 
storage technologies in 2019, according to the International Energy Agency (IEA), with only $5 \%$ of the total capacity provided by batteries.

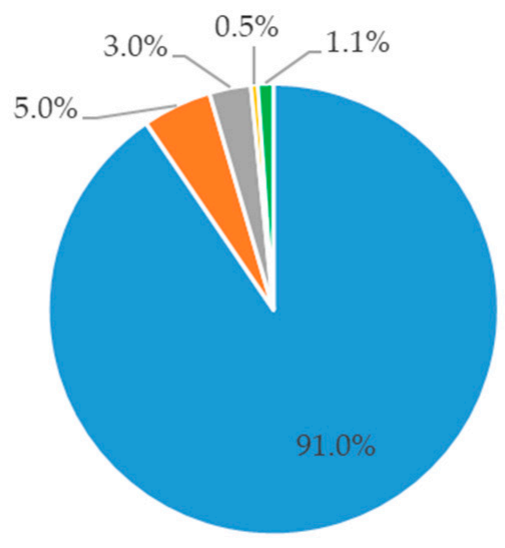

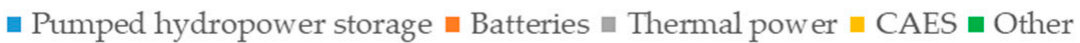

Figure 1. Installed capacity from energy storage technologies, 2019. Source: IEA.

To date, many types of redox flow batteries have been proposed depending on the redox couples used. All-vanadium [8,9], zinc-bromine [10,11], all-iron [12], semi-solid lithium [13] and hydrogen-bromine [14] are some of the most common types of redox flow batteries (RFB) that can be found in the literature. Since Skyllas-Kazacos et al. [15,16] suggested a Vanadium Redox Flow Battery (VRFB) in 1985, this electrochemical energy storage device has experimented a major development, making it one of the most popular flow batteries these days [17]. Flow batteries are a remarkable option for the large-scale energy storage issue due to their scalability, design flexibility, long life cycle, low maintenance and good safety systems $[18,19]$. Table 1 summarizes the main characteristics of flow batteries as well as other type of energy storage systems. It is important also to highlight the main advantages that flow batteries offer [18,20,21]:

- Independence between peak power and the energy capacity: as the former depends on the dimension of the stack, the latter is related to the dimension of the tanks and hence the quantity of electrolyte stored. In some conventional technologies, such as the lithium-ion batteries, the two parameters cannot be divided.

- Possibility of changing the electrolyte of the storage tanks while working.

- The security of the process and its long life cycle make the LCOS (Levelized Cost of Storage) one of the most important parameters of the battery [22].

- Using vanadium in both anolyte and catholyte. The cross-mixing species due to the non-ideal ion exchange membrane occurs, but since vanadium is used in both sides, the loss of capacity is not definitive: the solutions could be shuffled and go back to the initial state. The battery could also be left unused for a long period of time with low loss of charge, because of the fact that both electrolytes are stored separately.

- Short response time: thanks to the fast electrochemical kinetics, the response time is brief if the electrodes are kept full of electrolyte and the pumps are ready to start working.

- Solution properties: the acid vanadium solution is inflammable, and even if it is toxic in solid state (especially $\mathrm{V}_{2} \mathrm{O}_{5}$.), this form is not present in the normal condition of working but when the solutions are made.

- On the other hand, the technology of VRFB is nowadays in an "early commercial" state [23] and is still facing some issues as [20]:

- Low specific energy and power: this is related mainly to the low cell voltage and the low solubility of the vanadium species (i.e., low number of ions reacting) within a limiting temperature range from $5^{\circ} \mathrm{C}$ to $40^{\circ} \mathrm{C}$. 
- Low energy density (e.g., 10 times less than Lithium-Ion batteries).

- $\quad$ High costs (energy Installation Cost of reference in 2016: 347 USD) [24].

- Shunt currents: some flow field designs inevitably introduce currents bypassing into the manifolds in the stack, resulting in parasitic losses of power and energy [25].

Table 1. Main characteristics of various Energy Storage Systems.

\begin{tabular}{ccccccc}
\hline EES & $\begin{array}{c}\text { Max Power } \\
\text { Rating (MW) }\end{array}$ & $\begin{array}{c}\text { Discharge } \\
\text { Time }\end{array}$ & $\begin{array}{c}\text { Max Cycles or } \\
\text { Lifetime }\end{array}$ & $\begin{array}{c}\text { Energy Density } \\
\mathbf{( W h / L )}\end{array}$ & $\begin{array}{c}\text { Efficiency } \\
\mathbf{( \% )}\end{array}$ & $\begin{array}{c}\text { Capital Cost } \\
\mathbf{( \$ / k W )}\end{array}$ \\
\hline Pumped Hydro & 1000 & $4-12 \mathrm{~h}$ & $30-60$ years & $0.2-2$ & $70-85$ & 165 \\
Compressed air & 1000 & $2-30 \mathrm{~h}$ & $20-40$ years & $2-6$ & $40-70$ & 105 \\
Flywheel & 20 & Secs-mins & $20,000-100,000$ & $20-80$ & $70-95$ & 11,520 \\
Lead-acid battery & 100 & 1 min-8 h & $6-40$ years & $50-80$ & $80-90$ & $1040(756)^{\mathrm{a}}$ \\
NaS battery & 100 & 1 min-8 h & $2500-4400$ & $150-300$ & $70-90$ & $2644(1860)^{\text {a }}$ \\
Li-ion battery & 100 & 1 min-8 h & $1000-10,000$ & $200-400$ & $85-95$ & $1084(756)^{\text {a }}$ \\
Redox Flow Battery & 100 & Hours & $12,000-14,000$ & $20-70$ & $60-85$ & $2220(1572)^{\text {a }}$ \\
\hline
\end{tabular}

a 2025 cost predictions [26].

Several plants based on VRFB technology have been installed worldwide since 1996, when Mitsubishi Chemicals installed a $200 \mathrm{~kW} / 800 \mathrm{kWh}$ power plant in Kashima-Kita (Japan) conceived for load-leveling [27]. In 2015, Hokkaido Electric Power Company (HEPCO) and Sumitomo Electric Industry completed the Minami Hayakita substation, with a rated output of $15 \mathrm{MW}$ and a capacity of $60 \mathrm{MWh}$. In Europe, it is worth to mention the project carried out in 2019 by the Fraunhofer institute to install a VRFB of 2 MW and 8 MWH in Pfinztal, Germany. The biggest plant projected so far is placed in northern China, where a VRFB of $200 \mathrm{MW}$ and $800 \mathrm{MWH}$ designed by Rongke Power and UniEnergy Technologies are being installed in the Dalian High-Tech area. In an overall view, flow batteries are still far from being a reference among the energy storage systems, as shown in Figure 2 .

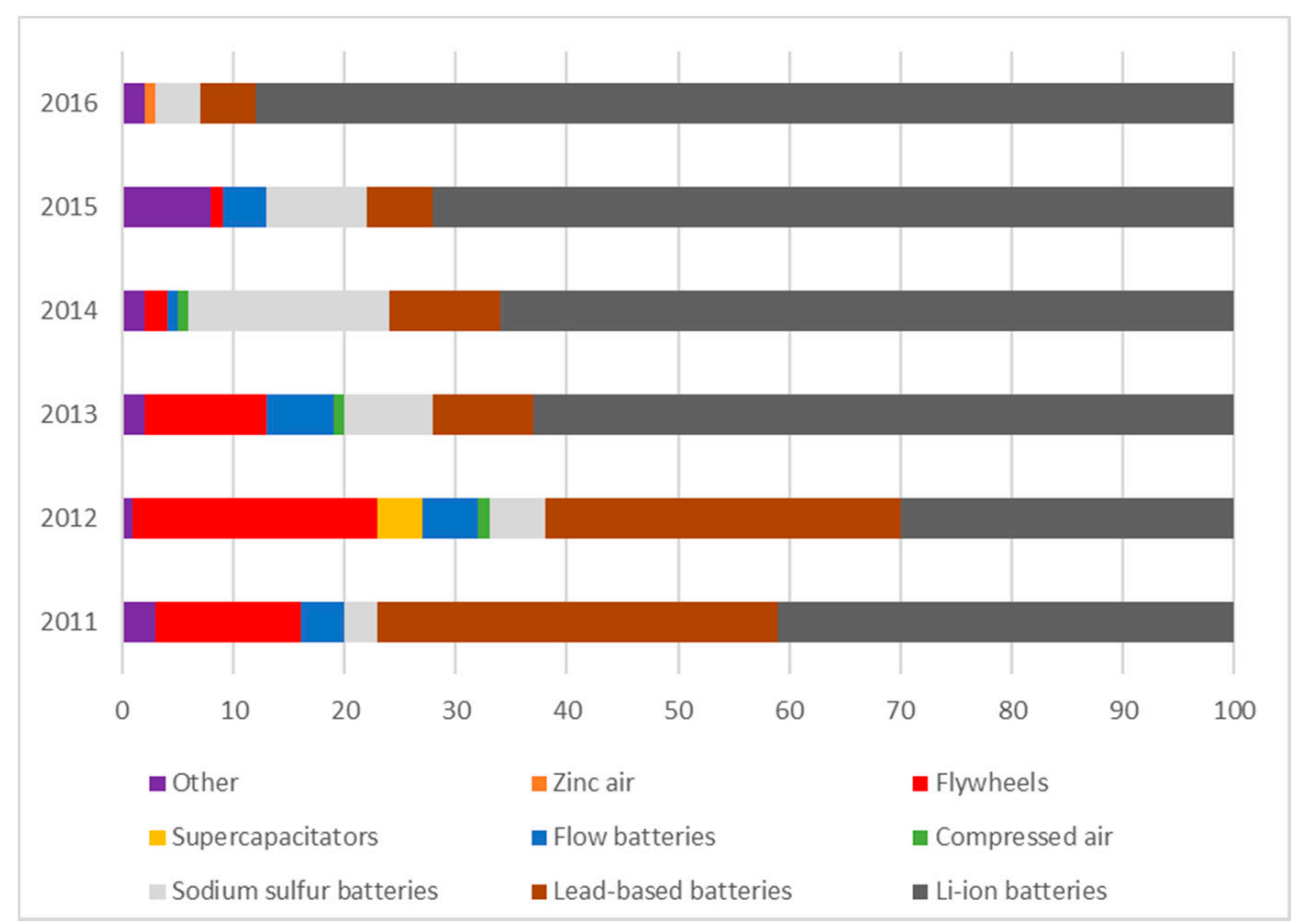

Figure 2. Technology mix in storage installations excluding pumped hydro from 2011 to 2016. Redrawn from [28]. 
The different components used in a VRFB as well as the size of the whole system influence the total cost. Since the power of the system is directly related with the dimension of the stack, smaller cell areas with high operating current will be required to reduce power costs. Nevertheless, operating at high current density lowers the electrochemical efficiency. Therefore, the $E / P$ ratio has an important influence in the cost and optimal operating point. The levelized cost of energy ( $L C O E)$, which is a measure of a power source that allows to compare different methods of electricity generation, determines the total cost of a generating plant over its lifetime divided by the lifetime energy production, see Equation (1).

$$
L C O E=\frac{\sum_{n=0}^{N}\left(C A P E X+O P E X /(1+i)^{n}\right)}{\sum_{n=0}^{N}\left(\mathrm{kWh}_{\text {initial,net }} /(1+i)^{n}\right)}
$$

where CAPEX and OPEX are the investment costs and operation and maintenance costs, respectively. $\mathrm{kWh}_{\text {initial,net }}$ is the initial net electricity production, $i$ represents the discount rate (\%) and $N$ the plant lifetime in years. Cost models for energy storage technologies can be found in the literature [29,30]. Figure 3 illustrates the system installation cost for different battery technologies in grid-scale energy storage systems. In the near future, VRFB will compete for least-cost commercial batteries with lead-acid, sodium-sulfur and lithium-ion technologies [22]. For that reason, the investigation for more efficient materials and configurations are an essential condition for the future commercial development of these batteries.

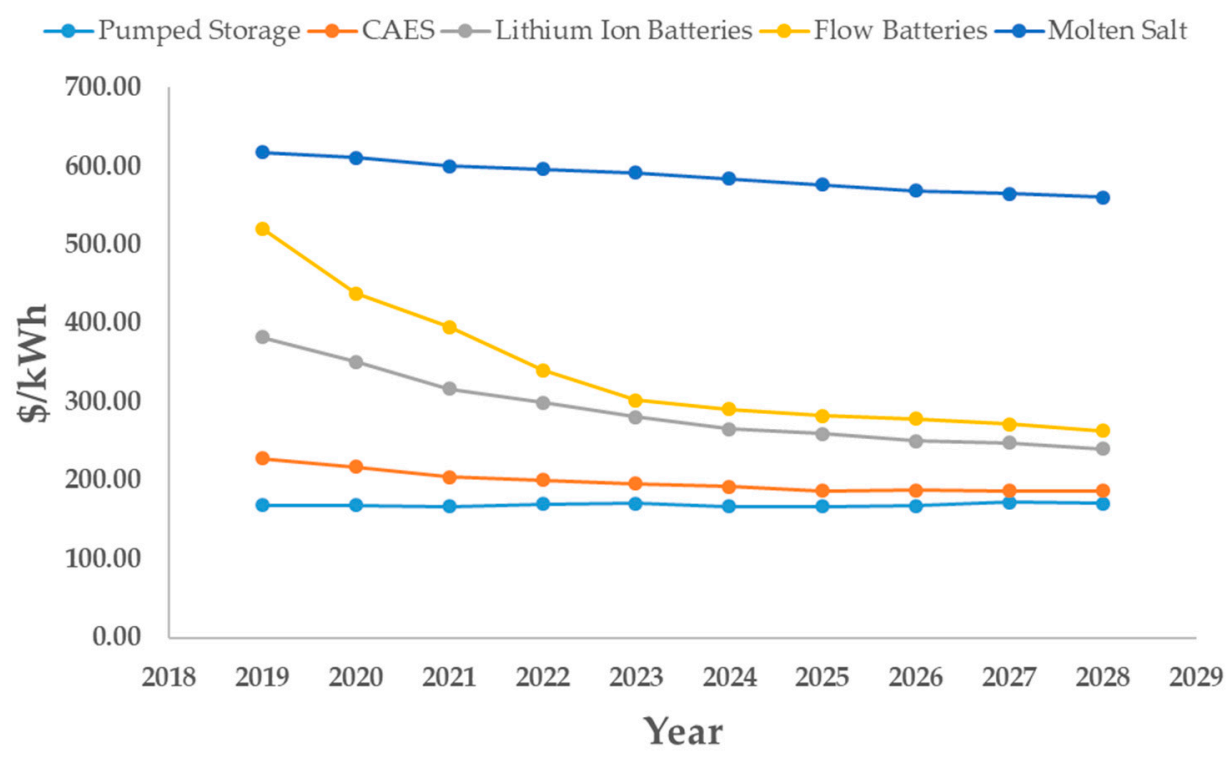

Figure 3. System installation cost (CAPEX) for different battery technologies in grid-scale energy storage systems. Source: Navigant Research.

In this article, we aim to complement other reviews available in the literature about vanadium redox flow batteries [18,31-34] with a comprehensive review on the recent studies and numerical models carried out by means of computational fluid dynamics (CFD) techniques. An overview of the state of the art of energy storage and flow batteries technology is provided in this introduction. The remainder of the manuscript is structured as follows: Section 2 is devoted to a general description of a VRFB and the battery operation. Section 3 relates with the main components that are involved in a VRFB. Some experimental studies with VRFB stacks, approaches for VRFB optimization with CFD based models as well as different flow field designs to improve the electrochemical performance are discussed in Section 4. Finally, the main conclusions and future directions are summarized in Section 5. 


\section{Operating Principle of a Vanadium Redox Flow Battery (VRFB)}

The VRFB consist of positive and negative electrodes and an ion exchange membrane. The electrolytes with the vanadium ions are stored in two tanks and they are recirculated through the set of cells (also known as stack) by mechanical pumps, see Figure 4. Within the stack, electrochemical redox reactions appear along the surface and inside the electrodes, which capture the released electrons and send them through the circuit, whereas the hydrogen cations (protons) pass through the ion-selective membrane and offset the charge equilibrium [35]. The reactions produced during cell operation are presented in Equations (2)-(4):

$$
\begin{gathered}
\text { Positive-side: } \mathrm{VO}_{2}{ }^{+}+2 \mathrm{H}^{+}+e^{-} \rightleftharpoons \mathrm{VO}^{2+}+\mathrm{H}_{2} \mathrm{O} \\
\text { Negative-side: } \mathrm{V}^{2+} \rightleftharpoons V^{3+}+e^{-} \\
\text {Cell reaction: } \mathrm{VO}_{2}{ }^{+}+\mathrm{V}^{2+}+2 \mathrm{H}^{+} \rightleftharpoons \mathrm{VO}^{2+}+V^{3+}+\mathrm{H}_{2} \mathrm{O}
\end{gathered}
$$

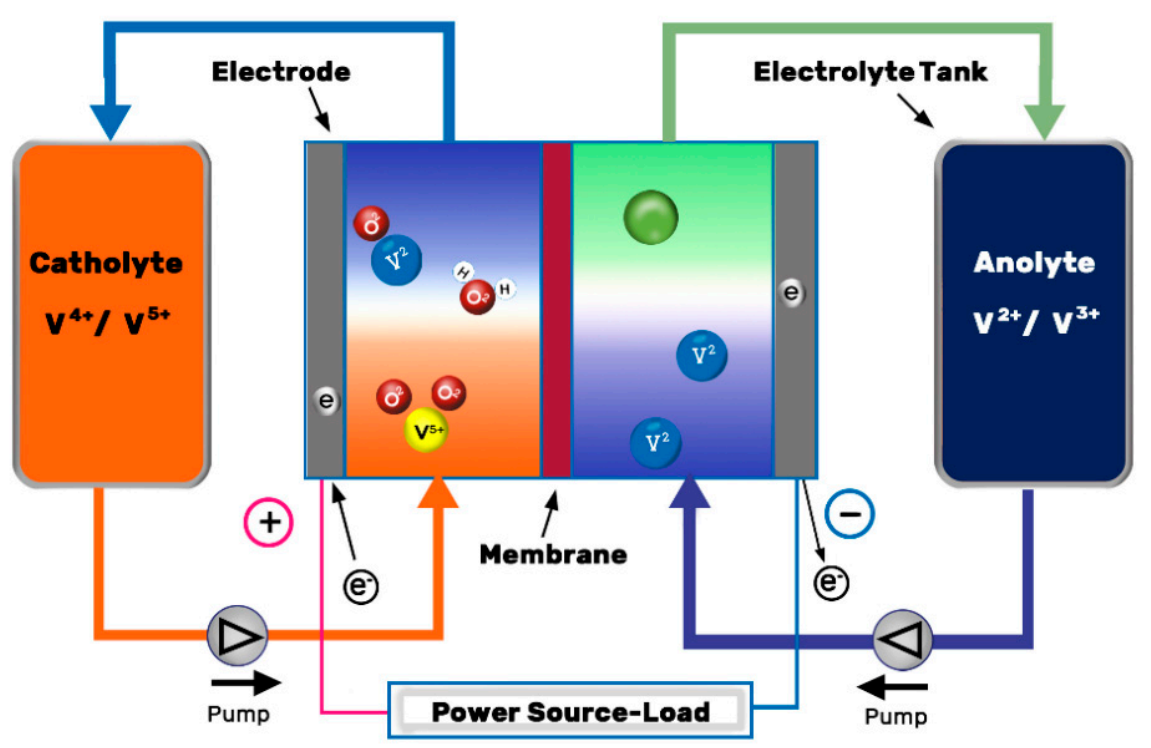

Figure 4. Schematic illustration of a VRFB. Redrawn from [31].

During the charge process, the $\mathrm{VO}^{2+}$ is oxidized to $\mathrm{VO}_{2}{ }^{+}$at the cathode, while the $\mathrm{V}^{2+}$ is reduced to $\mathrm{V}^{3+}$ at the anode. The latter is the slowest of all four reactions, and the charge transfer resistance (CTR) of the positive half-cell at any $\mathrm{SoC}$ is negligible compared to the negative half-cell [36]. That is the reason why negative electrode electrochemical activity needs to be enhanced.

The equilibrium potential at one of the electrodes is calculated by the Nernst equation, defined by Equation (5), which describes the potential difference between the electrolyte and the electrode when no reaction is given inside the cell.

$$
E=E_{0}+\frac{R T}{n F} \ln \left(\frac{C_{\text {oxidized species }}}{C_{\text {reduced species }}} \cdot \frac{\gamma_{\text {oxidized speies }}}{\gamma_{\text {reduced species }}}\right)
$$

where $E$ is the potential difference and $E_{0}$ is the standard reduction potential, $R$ is the universal gas constant, $T$ is the absolute temperature, $n$ is the number of equivalents transferred per mole of species reduced or oxidized, $F$ is Faraday's constant, $C$ is the ionic concentration, and $\gamma$ is the activity coefficient of the species.

Each potential depends on the reactions defined in Equations (2) and (3), where the cathode's (1) potential equals $1.0 \mathrm{~V}$ and anode's (2) potential equals $-0.26 \mathrm{~V}$ (both potentials 
are calculated using the Nernst equation). According to [37], the standard cell voltage is calculated by Equation (6):

$$
E=E_{0}+E_{o}=\Delta V_{+-}=V_{+}-V_{-}=1.0-(-0.26)=1.26 \mathrm{~V}
$$

However, the real cell exhibits a standard cell voltage of $E^{\prime}{ }_{0}=1.4 \mathrm{~V}$ when side effects (e.g., the Donnan potential at the membrane surface) are taken into consideration [37]. Furthermore, the OCV (Open-Circuit Voltage) varies with the SoC (State of Charge) of the electrodes, as shown in Equation (7) [21].

$$
E_{\mathrm{OCV}}=E_{o}^{\prime}+\frac{R T}{n F} \ln \frac{\mathrm{SoC}_{+} \mathrm{SoC}_{-}}{\left(1-\mathrm{SoC}_{+}\right)\left(1-\mathrm{SoC}_{-}\right)}
$$

The ideal battery would be able to provide (discharge) the same energy that would have being stored up previously (charge), and the concept of efficiency is defined in three different ways [38]:

1. Coulombic Efficiency (CE)-or current efficiency-refers to the ratio of the total charge (in Amperes-hour) delivered by the battery to the charged stored up.

2. Voltage Efficiency (VE) is the ratio of the average discharged voltage to the average charged voltage.

3. The Energy Efficiency (EE) is defined in Equation (8) as the ratio of energy (in Wattshour) discharged to charged energy. The EE is a key parameter of the battery's overall performance and it can be related to the $\mathrm{CE}$ and $\mathrm{VE}$ as follows:

$$
\eta_{E}=\eta_{C} \cdot \eta_{V}
$$

The efficiency of the process is called Coulombic efficiency (or Current Efficiency) and depends on several factors: (1) an optimal electrolyte flow rate coupled with the electrochemical reaction rate that allows reactions to occur before the electrolyte returns to the storage tanks, (2) an efficient ion-selective membrane that prevents the cross-mixing of the vanadium ions, (3) an even distribution of the electrolyte along the electrode to avoid potential differences $[39,40]$.

\section{Main Parts of a Vanadium Redox Flow Battery}

VRFB essentially consists of two key elements: the cell stacks, where several cells are assembled with the aim of converting chemical energy into electricity in a reversible process, and the tanks of electrolytes where energy is stored. In this Section, the main elements of a VRFB are discussed: the electrolyte, the carbon felt electrodes and the ion exchange membrane, respectively.

\subsection{Electrolyte}

In a VRFB, the electrolyte is composed of active species and supporting electrolytes. Traditional VRFBs use vanadium ions dissolved in sulphuric acid. The ideal redox couple would be one with high energy density, high nominal voltage and highly reversible redox kinetics [41]. Additionally, it would be desirable to be stable enough to allow a high $D o D$ and $\mathrm{SoC}$ with high-capacity retention, ideally a symmetric system, as reported by Potash et al. [42], as well as environmentally sustainable. With the aim of improving the electrolyte technology, the development of organic active materials is presented as one of the most promising alternatives to vanadium technology even though it still lacks the necessary technological development [43]. Among the different families of organic compounds, the use of quinone pairs has been an object of intensive research for their use in flow batteries due to their stable and reversible nature in aqueous medium [44].

Furthermore, the supporting electrolyte, which includes organic or aqueous solvent, buffer and/or additives, is essential in the electrochemical behavior of the cell. Nonaqueous systems, a priori, have a wider potential window but aqueous systems present 
significant advantages. Leung et al. [43] reviewed lower cost and higher ionic mobility compared to non-aqueous electrolytes in addition to a lower environmental impact.

Among the different research works on aqueous organic electrolyte for redox flow systems (AORFB) reported in the literature there is a great disparity of data regarding energy density and stability (number of cycles) $[45,46]$, with very few studies combining good results in both parameters, see the work of Liu et al. [47]. Choi et al. [48] covered in depth the main issues and challenges for VRFB electrolytes. Table 2 illustrates the main characteristics of different generations of VRFB, see Skyllas-Kazacos et al. [49].

Table 2. Main characteristics of different generations of VRFBs [49].

\begin{tabular}{ccccc}
\hline Generation & $\begin{array}{c}\text { Max. Vanadium } \\
\text { Concentration }\end{array}$ & $\begin{array}{c}\text { Average } \\
\text { Discharge } \\
\text { Voltage (V) }\end{array}$ & $\begin{array}{c}\text { Energy Density } \\
\text { for 80\% SOC } \\
\text { Range (Wh/L) }\end{array}$ & $\begin{array}{c}\text { Specific Energy } \\
\text { for 80\% SOC } \\
\text { Range (Wh/kg) }\end{array}$ \\
\hline $\mathrm{V} / \mathrm{V}$ in $\mathrm{H}_{2} \mathrm{SO}_{4}$ & $1.5-3 \mathrm{M}$ & 1.2 & $38-50$ & $15-25$ \\
$\mathrm{~V}-\mathrm{halide} \mathrm{in}$ & $2-3.5 \mathrm{M}$ & 1.0 & $42-63$ & $25-50$ \\
$\mathrm{HCl} / \mathrm{HBr}$ & $2.3 \mathrm{M}$ & 1.2 & $35-40^{\mathrm{a}}$ & $35-70^{\mathrm{a}}$ \\
$\mathrm{V} / \mathrm{V} \mathrm{in} \mathrm{HCl}$ & $1.5 \mathrm{M}$ & 0.75 & $20-25$ & $15-20$ \\
$\mathrm{Fe} / \mathrm{V}$ & $1.5 \mathrm{M}$ & 1.2 & $25-30$ & $20-25$ \\
$\mathrm{Fe}-\mathrm{V} / 2 \mathrm{~V}$ & & & &
\end{tabular}

a Results at $70 \%$ SoC.

\subsection{Electrodes}

The electrode is one of the essential parts of a VRFB. It is responsible for capturing the electrons released in the chemical reactions, getting electric current from the cells when discharging, and providing electric current to the cell when charging. Despite the above-mentioned, the electrode does not participate in the reaction itself, but provides the active sites for the reactions to be given. The ideal electrode should fulfill the following characteristics [50].

- To be chemically stable to bear the strong acids dissolved within the aqueous electrolyte.

- To be made of a material with favorable electrocatalytic activity.

- Provide a three-dimensional network structure with an optimal porosity in order to reach the optimal pressure-drop/reaction-rate equilibrium and a uniform electrolyte distribution.

- Operate correctly in the voltage range of the battery.

- To have excellent electrical conductivity for faster charge transfer reactions with low internal resistance.

- Low cost.

In its most widespread configuration, the electrodes are used in the form of graphite felts (GF), a porous material through which the electrolyte flows. However, this material has a very poor wettability with aqueous electrolytes, so a pretreatment of the surface is usually given to achieve a sufficiently hydrophilic surface [51]. Table 3 classifies different types of electrodes studied in VRFB systems. Leung et al. [52] showed that removing the distance between the electrodes (i.e., the membrane, electrodes, and current collectors are in direct contact), reduces the internal ohmic resistance, facilitating mass transport and helping to minimize the voltage drop across the battery. This configuration, known as zero-gap flow field design (see Figure 5), has also been reported to achieve significantly high power densities [53]. 
Table 3. Electrodes used as negative and positive electrode components.

\begin{tabular}{|c|c|c|c|}
\hline Electrode Type & $\begin{array}{l}\text { Charge/Discharge } \\
\text { Potential Range (V) }\end{array}$ & $\begin{array}{c}\text { Energy } \\
\text { Efficiency (\%) }\end{array}$ & Ref. \\
\hline \multicolumn{4}{|c|}{ Negative Electrode } \\
\hline $\mathrm{ZrO}_{2}$ nanoparticle embedded carbon nanofibers & 0.7 and 1.7 & 73.3 & He et al. [54] \\
\hline $\mathrm{MnO}_{2}$ nanosheet array-decorated carbon paper & 0.7 and 1.7 & 66.4 & Jiang et al. [55] \\
\hline Titanium nitrite coated graphite felt & 0.9 and 1.7 & 77.4 & Wei et al. [56] \\
\hline Flexible electrospun carbon nanofiber embedded with $\mathrm{TiO}_{2}$ & 0.7 and 1.7 & 75 & He et al. [57] \\
\hline Electrospun nitrogen-doped carbon nanofiber & 0.7 and 1.7 & 72.8 & He et al. [58] \\
\hline \multicolumn{4}{|c|}{ Positive Electrode } \\
\hline 3D graphene-nanowall-decorated carbon felts & 0.7 and 1.7 & 90 & Li et al. [59] \\
\hline Graphene deposited carbon felt (CF) & 0.7 and 1.75 & 85 & Xia et al. [60] \\
\hline $\mathrm{Mn}_{3} \mathrm{O}_{4} /$ multi-walled carbon nanotube modified graphite felt & 0.7 and 1.7 & 84.6 & He et al. [61] \\
\hline $\mathrm{Co}_{2}$-activated graphite felt & 0.7 and 1.6 & 84 & Chang et al. [62] \\
\hline Biomass-derived electrode & 0.9 and 1.65 & 86.3 & Zhang et al. [63] \\
\hline
\end{tabular}

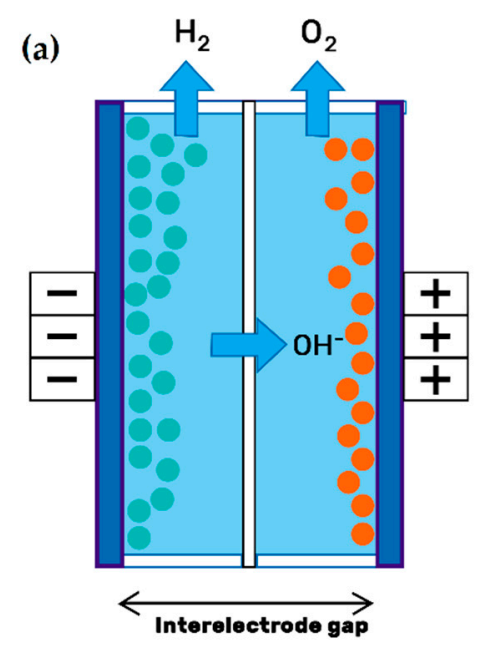

Figure 5. Electrode configuration: (a) Traditional setup; (b) zero-gap design of porous electrodes. Redrawn from [64].

To further improve the electrochemical properties (catalytic activity, electrical conductivity and wettability) and the useful life [36] (durability of the electrodes against chemical attack, overload, aging and corrosion) of carbon electrodes, different superficial treatments are under research [65]. Xia et al. [60] obtained promising results with a graphene modified carbon felt electrode with a coating process for a VRFB. Recently, Lv et al. [66] studied biomass carbon materials in order to obtain new low cost, renewable and sustainable energy storage systems. Reviews in this field can be found in the literature summarizing the recent progress on electrode materials and the development and application of carbon fiber in batteries $[67,68]$.

There are two main electrode designs: the "flow-through"(FT) and the "flow-by"(FB) configuration, as illustrated in Figure 6 [32]. 
(a)

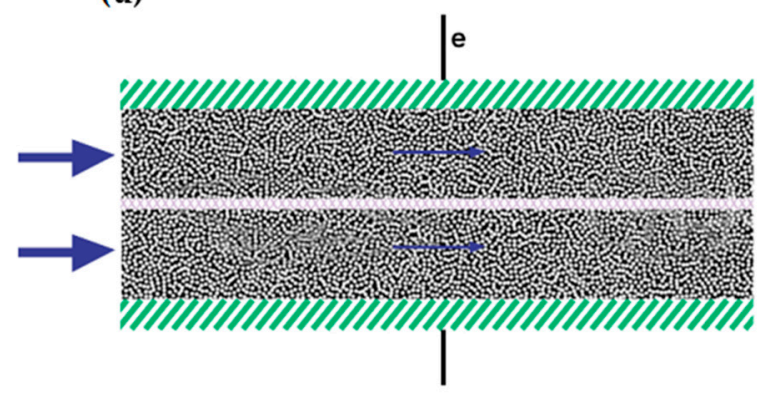

IIII, Current collector

Flow channel (b)

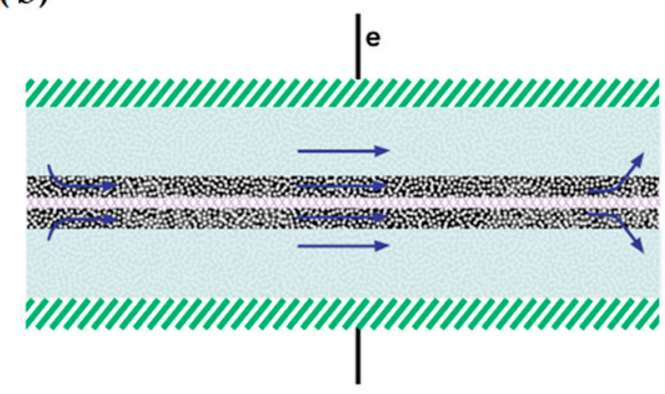

Membrane

Figure 6. Electrode designs: (a) Flow-through; (b) Flow-by electrode configurations. Redrawn from [32].

The "flow-by" configuration was presented as the best flow field option long ago, as shown in the study of Trainham et al. [69]. Compared with the FT design, the addition of a flow field improves the distribution uniformity of the electrolyte through the electrode, particularly at flow rates [70,71]. Increasing the flow rate also increases the pumping power, but this effect is offset by the lowered overpotential, indicating that there is an optimal flow rate where maximum efficiency can be achieved [71]. In 2015, Reed et al. [70] experimented with a flow-through configuration VRFB at high density currents. Initially, they obtained too high temperatures related to the high pressure drop of the model; then, they decided to include a "flow-by" configuration with an interdigitated pattern, working at a higher flow rate while reducing the pressure drop. The new design reached an outstanding EE of $75 \%$ at $320 \mathrm{~mA} / \mathrm{cm}^{2}$. In 2016 they carried out another flow-through/flow-by comparison, concluding that the FT configuration only outperformed the FB one at low flow rates $(400 \mathrm{cc} / \mathrm{min})$ [72]. The main advantages of the flow fields on the flow battery system summarize as follows [32]:

- Using thinner electrodes implies lower ohmic losses (increasing the efficiency).

- The enhancement of localized mass transfer in the porous electrode because the flow is driven through by the forced convection associated with the pressure drop along the flow field.

- Higher limiting current density and peak power density.

\subsection{Ion-Exchange Membranes}

In general, the energy efficiency and cyclability of electrochemical cells with dissolved redox materials are intrinsically connected to the stability, ion conductivity and transport selectivity of the ion exchange membrane. The materials currently used for membranes are mostly material previously designed from other applications that have different functional requirements.

The use of alternative redox materials to vanadium (organic and/or organometallic), which presents complex phenomena of transport of ionic species, together with increasingly demanding operating conditions in redox flow batteries towards higher energy and current densities must be taken into account for the design of a new generation of membrane materials [73]. Most of redox based flow batteries (RFBs) employ polymeric membranes or separators, both anion exchange (AEM) and cation exchange (PEM) membranes.

Among the commercial options available in the market, perfluorinated membranes $\left(\mathrm{Nafion}^{\circledR}\right.$ ) are the most widespread for use in aqueous redox flow systems due to their excellent chemical stability and high ionic conductivity, see the work of Reed et al. [70]. Nonetheless, according to the study carried by Li et al. [35], these commercial alternatives have a low coulombic efficiency and a high cost. Its extensive use in fuel cells and also in vanadium technology has helped to check its viability for its use, which require high-performance membranes (fuel cells) and/or high stability against corrosive media. 
However, its efficiency in terms of ion selectivity for the vanadium system results in a loss of EC.

In the case of Anion Exchange Membranes (AEM), they offer better performance in terms of selectivity respect to the vanadium system, but are generally lower in conductivity than the PEMs previously mentioned. Several studies have reported this type of membrane in aqueous-organic systems [74,75]. In these cases and taking advantage of the lower requirements of the organic electrolyte, commercial membranes of lower cost are the most common used, see the work of $\mathrm{Hu}$ et al. [74]. According to Pezeshki et al. [76], membranes of the polyarylene type, either anionic or cationic, show remarkable properties in comparison to commercial membranes based on perfluorosulfonic polymers. However, chemical stability is usually a challenge for such materials.

Among the most interesting materials to manufacture membranes when chemical resistance and stability against oxidation are required, polybenzimidazole (PBI) is very promising. PBI membranes have been widely investigated in nanofiltration applications [77] and in high-temperature fuel cells [78]. PBI is able of absorbing acid and being protonated, developing anion exchange properties, as is the case of HMT-PBI [79], or for cation exchange, introducing sulfonic groups in the polymer structure [80]. PBI can also be built as an asymmetric porous membrane, see the work of Gubler et al. [73]. The review of Shi et al. [81] covered all the recent developments, challenges and future directions of membranes in non-aqueous redox flow batteries.

\section{Experimental and Numerical Modelling of VRFB}

In this Section, experimental studies with VRFB stacks, different approaches for VRFB optimization by means of CFD based models as well as different flow field designs to improve the electrochemical performance and are presented.

\subsection{Experimental Studies with VRFB Stacks}

Generally, due to the cost of large experimental facilities, the research in the field of VRFBs is carried out with short stacks or with small-size cells with active areas no longer than $10 \mathrm{~cm}^{2}$. Besides, experimental studies can barely quantify most of the component parameters that govern the flow battery operation. Schreiber et al. [82] designed a VRFB system with $10 \mathrm{~kW}$ in power and $100 \mathrm{kWh}$ in energy (FB10/100 battery) and with a smart controller. A multi-stage-operation mode was defined leading to an improvement in the overall battery performance compared to all stacks in operation. Kim et al. [83] developed a prototype VRFB system with a mixed acid supporting electrolyte. The $1 \mathrm{~kW} / 1 \mathrm{kWh}$ VRFB system presented, which was evaluated experimentally and numerically, delivered more than $1.1 \mathrm{~kW}$ at $15-85 \%$ SoC with an energy efficiency of $82 \%$. A lower capital cost and a simplified system design was also reported with the use of mixed acid electrolytes. In the work of Bryans et al. [84], the $200 \mathrm{~kW} / 400 \mathrm{kWh}$ VRFB system placed in the energy station of Martigny (Switzerland) was analyzed and characterized with the aim of confirming its optimal application. They reported an overall efficiency of $48-60 \%$ and reached to the conclusion that would be suitable for the charging of electric vehicles. Guarnieri et al. [85] have also performed an experimental study with the design, construction and operation of a VRFB test facility of industrial size. The system comprises a 40 cell stack with a $600 \mathrm{~cm}^{2}$ active area to deliver $4 \mathrm{~kW}$, and two tanks with $550 \mathrm{~L}$ of vanadium solution. Their results showed a peak power of $8.9 \mathrm{~kW}$ with a stack specific power of $77 \mathrm{~W} / \mathrm{kg}$ and a maximum current density of $665 \mathrm{~mA} / \mathrm{cm}^{2}$. Recently, Trovò [86] have used this test facility to develop a battery management system (BMS) as a valuable tool for controlling and testing a VRFB. Park et al. [87] constructed an all-vanadium RFB stack with 31 cells and an electrode surface area of $2714 \mathrm{~cm}^{2}$. The system was tested at current densities of 60 and $90 \mathrm{~mA} / \mathrm{cm}^{2}$ and confirmed that was suitable for electric storage with high efficiency. 


\subsection{Numerical Modeling of VRFB Cells and Different Flow Field Architectures with CFD Tools}

In order to develop and optimize the systems based on redox flow technologies, a deep knowledge of the main physical phenomena is critical. It could be very helpful to regulate the operation and performance of the battery and to quantify the corresponding performance losses. Therefore, the Computational Fluid Dynamic based simulations (CFD) are a powerful tool which allows the design of simulations with different flow rates, load states, material properties and distribution channels. This useful technique for numerical simulations, combined with a validation of the computational results by means of experimental data, provides valuable information of the problems associated with mass transport in flow batteries.

Wu et al. [88] manufactured a 5 KW VRB stack composed by 40 cells and performed a CFD study to analyze the flow and pressure distribution. This stack, with a zigzag coverplate and multi-distribution channel, reached an EE of $82.8 \%$ at $50 \mathrm{~mA} / \mathrm{cm}^{2}$. However, in the scientific community, the challenge of modeling and simulation of these systems has been solved with different approaches and/or approximations to study in detail more physical quantities. Most of them consider a simplified geometry, even without channels, which is not a representative configuration of the flow field used in potential industrial applications. Usually, this setup results in an uniform distribution of the variables in one direction, simplifying the initial three-dimensional model into a two-dimensional one, see the study of Barton et al. [89]. This strategy based on the geometry simplification allows a prompt understanding of properties such as the transport and electrochemical phenomena which characterize the flow battery performance, but does not provide a direct perception of the fluid dynamics occurring along the channels and the porous medium.

The application of CFD techniques allow to evaluate the influence of several parameters, such as electrodes thicknesses, cell active areas, flow rates and channel designs, as shown in the study of Knudsen et al. [90] for high-power flow batteries. Furthermore, Kumar et al. [91] studied the influence of electrode intrusion into the flow channel. To that end, numerical simulations were performed taking into account that due to the compression a portion of the electrode protruded into the flow channel. Three different electrode thicknesses were evaluated $(3 \mathrm{~mm}, 6 \mathrm{~mm}$ and $9 \mathrm{~mm}$ ) and concluded that an uncompressed thickness of $6 \mathrm{~mm}$ provided the optimal electrochemical performance. Recently, Sun et al. [92] showed that reactants can be uniformly distributed in the porous electrodes by arranging the aligned fibers with the orientation perpendicular to the flow channels. Ozgoli et al. [93] developed different models to investigate the electrochemical and hydrodynamic characteristics. A two-dimensional model was chosen to study the vanadium distribution at different levels of the electrodes, profiles across them and the membrane along with a sensitivity analysis of several physical properties. On the other hand, a three-dimensional model was used to focus the research in the dynamic behavior of the fluid within the porous electrodes, using different configurations of the inlet and outlet to obtain the optimal one with regard to pressure drop and performance.

A transient and non-isothermal 3D model of a VRFB is developed in the study carried out by Oh et al. [94] with the aim of analyzing the charge-discharge curves and the local potential profiles across the electrode. A three-dimensional isothermal and stationary model is proposed in the work of Ma et al. [95], where the results in a half-cell were compared with simulation data extracted from literature sources. They investigated parameters such as the distribution of current density, velocity, vanadium concentration and overpotential at several heights of a porous electrode. Wang et al. [96] combined a non-isothermal 3D model with electrolyte tanks in order to make a simulation of the charge and discharge curves. The evolution of the current density, concentration and temperature distributions were studied and validated alongside experimental data. Nevertheless, those authors did not take into account the effect of vanadium ion migration and secondary reactions in their computational models. That effect was modeled by describing the transport of species with a dilute solution approach. 
The study of different flow field distributions in order to get an optimum balance between pressure losses and electrochemical reaction rate (i.e., maximum efficiency), is one of the key developments that the VRFB needs if the early commercialization-state is expected [97]. In addition, other considerations must be taken into consideration:

- The enhancement of the porosity and the optimization of the electrode's thickness in order to improve the velocity and decrease the resistance to the mass transfer [98].

- Lower velocities will cause higher overpotential, resulting in side reactions and corrosion [95].

- $\quad$ For low-intermediate Reynolds numbers $(R e)$, the effect of the canalization and stagnant zones becomes relevant [99]. Re is the ratio of inertial forces to viscous forces and is obtained from a combination of the geometrical characteristics of the channel, the fluid flow rate and its properties, see Equation (9).

$$
R e=\frac{V \times D \times \rho}{\mu}
$$

where $\rho$ and $\mu$ correspond to the density and dynamic viscosity of the electrolyte, $D$ is the characteristic length of the channel and $V$ is the fluid velocity.

Different classic flow channel designs (serpentine, interdigitated, parallel, spiral) have been analyzed over the years to evaluate which one is the most adequate for an efficient VRFB. Several studies have concluded that serpentine flow field design (see Figure 7a) and interdigitated flow field design (see Figure $7 \mathrm{~b}$ ) provide the best electrochemical performance [71,99-101]. The parallel pattern was dropped as a reference flow field because even if it has one of the lowest pressure drops, it also exhibit poor energy efficiencies (e.g., worse than a flow-through configuration [71]), and less efficient mass transfer than the interdigitated flow channel [102]. In addition, Chen et al. [103] reported in 2011 the parallel pattern requirement for an optimized inner flow field structure by the utilization of CFD tools.

(a)
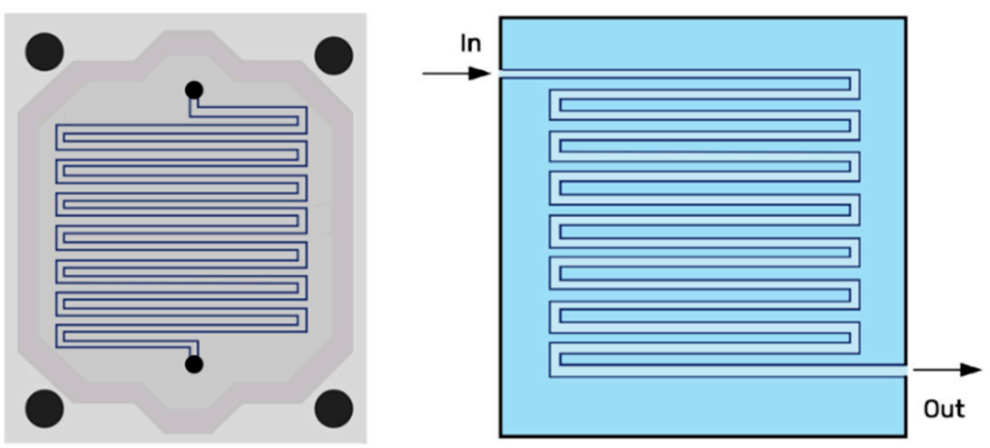

(b)
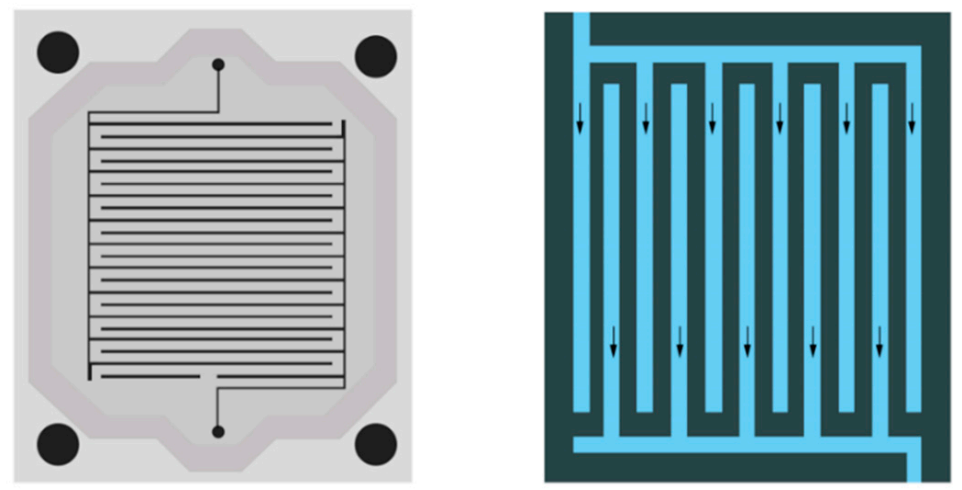

Figure 7. Flow channel designs: (a) Serpentine flow field; (b) Interdigitated flow field configuration. Redrawn from [20]. 
Adding a flow field increases the crossover rate of the vanadium ions due to the strong convection effect, which slightly lowers the Coulombic Efficiency. However, the uniform distribution of the electrolyte that provides the flow field decreases the polarization, improving the voltage efficiency while the overall efficiency is also enhanced [71]. Jiang et al. [104], using a 3D numerical simulation, slightly sacrificed the Coulombic Efficiency with a high conductivity membrane in order to achieve higher Voltage Efficiency. This membrane combined with a uniform distribution of the electrolyte provided by the interdigitated flow field, allowed them to reach an outstanding energy efficiency of $80.83 \%$ and a high stability of operation during the time at high current densities $(600 \mathrm{~mA} / \mathrm{cm} 2)$. Flow distributions are extremely difficult to be measured directly through experimental methods; therefore, optical measurements and numerical studies are an effective approach to simulate the flow transport [105]. The most common CFD model is the three-dimensional, because it considers the electrolyte movements under the ribs and the flow channels (see Figure 8), which are relevant factors as an important number of the reactions occur within the porous electrode, and the overpotential depends on the distribution in both the in-plane and through-plane directions [71]. On the other hand, 2D models are commonly used to study the flow distribution from the top view of the flow field scheme, as the work carried out by Yaji et al. [106], who studied the optimized flow field distribution and obtained a "branched" interdigitated model. However, there are also some researchers, as Ishitobi et al. [107], that studied the velocity, concentration of reactants, and overpotential at different SoCs from a side-view of the stack. Furthermore, this model has been also used in some heat transference studies along the stack, reporting the importance of the temperature at the outlet caused by the heat (of the exothermic reactions) transfer of the electrolyte out of the stack $[94,108]$.

(a)

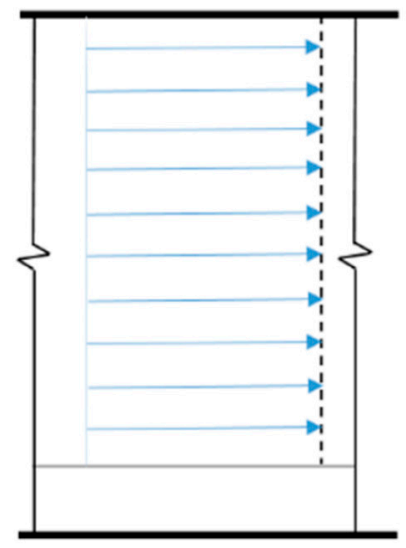

(b)

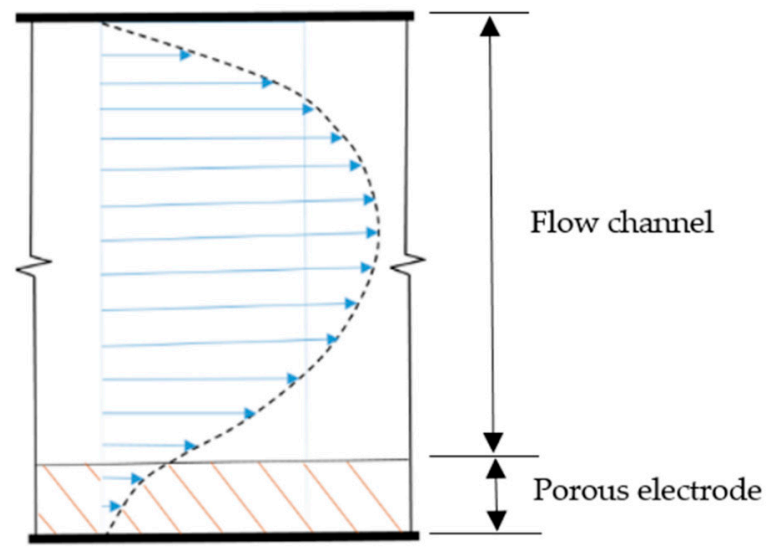

Figure 8. Electrolyte flow distribution: (a) Flow field distribution at the entrance of the flow channel; (b) an intermediate point, where the flow penetrates into the porous electrode. Redrawn from [32].

As mentioned above, 3D models have been a useful tool when studying the differences between the different flow patterns, describing the advantages and disadvantages between the most popular flow architectures: the serpentine flow field (SFF) and the interdigitated flow field (IFF). Latha et al. [109] studied both experimentally and numerically the flow distribution and pressure drop with SFF and IFF configurations, obtaining less pressure drops and better electrochemical performance for the IFF design. However, other studies have reported that SFF have a better performance than the IFF [101], with low charging voltage and high discharging voltage [56], especially at low flow rates. On the other hand, according to Messaggi et al. [101], the IFF has an homogeneous reaction rate and much less pressure drop than the SFF at high flow rates [102]. Additionally, Ke et al. [110] concluded that with an IFF design a higher fraction of the electrolyte penetrates into the porous electrode (i.e., improving the reaction rate) in comparison with a SFF. 
Another variation of the classic flow fields are the multi-distribution channels. Yin et al. [102] studied the differences between a single-inlet and multi-inlet interdigitated flow field, using a 3D model. As expected, it was reported a pressure drop 50\% lower in the multidistribution configuration under the same flow rate than the single-inlet one. However, the pressure drop of the multi-distribution significantly decreased at low flow rates, resulting in a non-desired uneven distribution. On the other hand, the single-distribution's flow field, electrical potential, current density and overpotential were uniformly distributed along the flow direction. Although the performance of the multi-distribution seems to be worse than the single-distribution at low flow rates, at high flow rates the distribution of the multi-inlet cell becomes uniform, leading to a better performance. Chen et al. [103] evaluated by means of a transient model the fluid dynamics behavior of the flow field with a parallel architecture and performed a comparison with experimental data. A broad vision on VRFB modeling based on CFD techniques is represented by the works of Yin et al. [102] and $\mathrm{Xu}$ et al. [71], who studied how the local distribution of physical quantities are affected by the flow field configuration. Yin et al. [102] made different computational simulations of a simplified geometry with both electrodes using an interdigitated flow field configuration, exploring different input/output schemes and evaluating their effects on the potential distribution, performance, pressure drop and current density. Furthermore, a sensitivity analysis was carried out on the flow velocity and on the channels' geometric dimension. On the other hand, in the work of Xu et al. [71], VRFBs with no field and with parallel and serpentine flow fields were evaluated in terms of pressure drop, performance and overpotential. They also defined an overall efficiency for each flow field configuration and reached to the conclusion that the serpentine flow field provided the best results with regard to efficiency and heterogeneity. Obtain a uniform electrolyte distribution in the reaction region is an important to optimize the performance of a VRFB. To that end, four different layout configurations were studied by Bortolin et al. [111] to analyze the electrolyte solution distribution system. Messaggi et al. [101] studied the local distribution of reaction rates for both serpentine and interdigitated flow fields, as illustrated in Figure 9, where an heterogeneous distribution of the reaction rate was noted using a serpentine flow field.
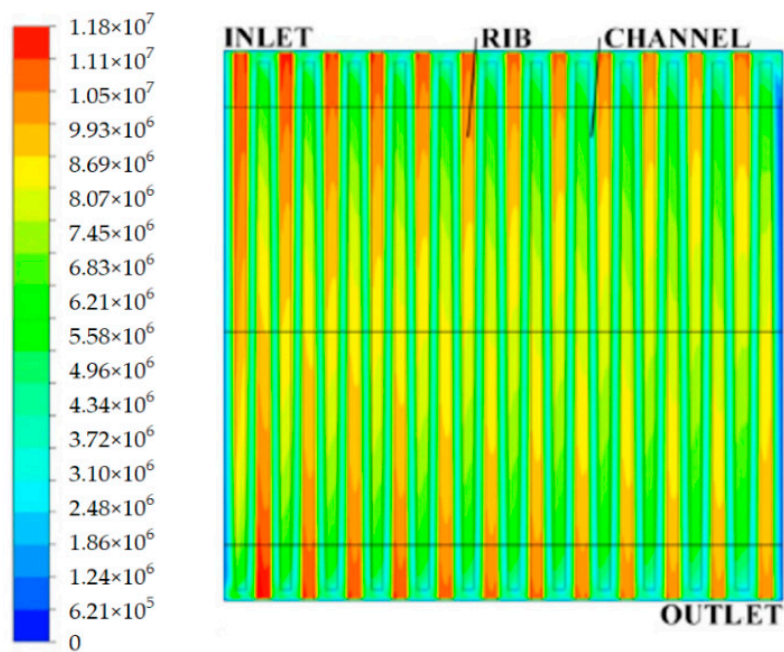

(a)

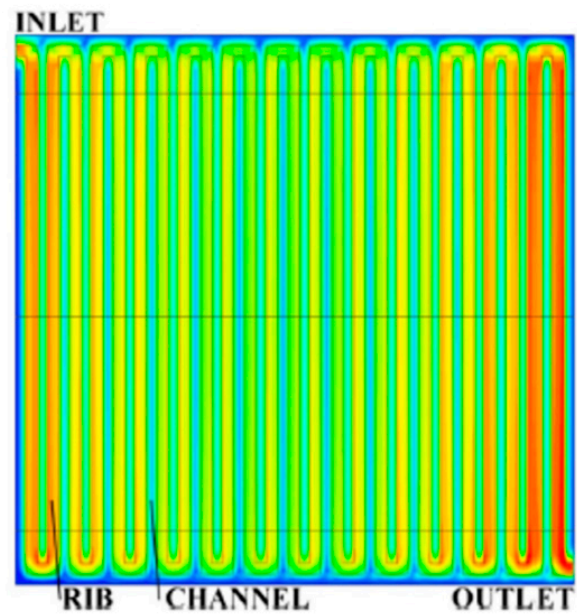

(b)

Figure 9. Distribution of reaction rates in a plane at the half-height of the electrode with: (a) Single serpentine geometry; (b) Interdigitated geometry [101].

Despite of the high performances of the IFF and the SFF architectures, the reduction of the overpotential is still a target to be reached. In 2017, Houser et al. [112] proposed two new flow field patterns, in order to give a solution for the above-mentioned overpotential 
issue: the Equal Path Length (EPL) and the Aspect Ratio (AR) models. They stated that, for a high performance RFB (i.e., high current density with low flow rate), pressure drop and parasitic pumping losses are relatively negligible. These designs could be described as a flow-by and flow-through flow field combination, where a simple pattern makes the entire volume of electrolyte to penetrate into a larger area of the porous electrode, eliminating the bypass flow and improving mass transport in comparison with the SFF and the IFF at the expense of higher pressure drop. The EPL model was reported to reach higher current densities than AR, but with less efficiency. They concluded that the AR design, with a more scalable design and higher EE, outperformed the EPL one.

Summarizing, CFD techniques emerge as a suitable resource to be taken into account to optimize the performance of VRFBs and to evaluate key parameters such as flow rate, flow distribution through the channels and electrodes and pressure drop. Table 4 reports some of the main parameters and the pressure drop values obtained with different types of flow fields that can be found in the literature.

Table 4. VRFBs main parameters and pressure drop values from different flow field configurations.

\begin{tabular}{|c|c|c|c|c|c|}
\hline Flow Field & $\begin{array}{c}\text { Flow Channel } \\
\text { Height-Width }(\mathrm{mm})\end{array}$ & $\begin{array}{c}\text { Electrode } \\
\text { Thickness (mm) }\end{array}$ & $\begin{array}{l}\text { Flow Rate } \\
(\mathrm{mL} / \mathrm{min})\end{array}$ & $\begin{array}{l}\text { Pressure Drop } \\
(\mathrm{Pa})\end{array}$ & Ref. \\
\hline No flow field & - & 4 & 30 & $3.6-21.2$ & [93] \\
\hline No flow field & - & 3 & $5-20$ & $957-4210$ & \multirow{3}{*}{ [71] } \\
\hline Serpentine & $3 \times 3$ & 3 & $5-20$ & $330-4768$ & \\
\hline Parallel & $3 \times 3$ & 3 & $5-20$ & $83-1170$ & \\
\hline Interdigitated (single-inlet) & $1.5 \times 1.5$ & 2 & 10 stoich * & $\sim 3.62$ & \multirow{2}{*}{ [102] } \\
\hline Interdigitated (multi-inlet) & $1.5 \times 1.5$ & 2 & 10 stoich * & $\sim 2.44$ & \\
\hline Serpentine & $3 \times 3$ & 3 & $0-122$ & $108.45-1297.28$ & \multirow{2}{*}{ [109] } \\
\hline Interdigitated & $3 \times 3$ & 3 & $0-122$ & 119.32-941.1 & \\
\hline Serpentine & $3 \times 3$ & $3-6-9$ & 114 & $\sim 2866-9508$ & \multirow{3}{*}{ [91] } \\
\hline Serpentine (two-way split) & $3 \times 3$ & $3-6-9$ & 114 & $\sim 1327-5484$ & \\
\hline Serpentine (three-way split) & $3 \times 3$ & $3-6-9$ & 114 & 2475-10362 & \\
\hline Serpentine & $1 \times 0.8$ & \multirow[t]{2}{*}{0.34} & $10-60$ & 12030-105950 & \multirow{2}{*}{ [101] } \\
\hline Interdigitated & $1 \times 0.8$ & & $10-60$ & 5010-20380 & \\
\hline Serpentine $\left(10 \mathrm{~cm}^{2}\right) 1$ channel & $1.016 \times 0.7874$ & $0.4-1.2-2.4$ & $10 * *$ & $\sim 101325$ & \multirow{5}{*}{ [90] } \\
\hline Serpentine $\left(50 \mathrm{~cm}^{2}\right) 4$ channels & $0.795 \times 0.795$ & $0.4-1.2-2.4$ & $10^{* *}$ & $\sim 151988$ & \\
\hline Interdigitated $\left(50 \mathrm{~cm}^{2}\right.$ loose $)$ & $0.8 \times 0.8$ & $0.4-1.2-2.4$ & $10^{* *}$ & $\sim 192518$ & \\
\hline Interdigitated (50 $\mathrm{cm}^{2}$ tight) & $0.8 \times 0.8$ & $0.4-1.2-2.4$ & $10 * *$ & $\sim 415432$ & \\
\hline Interdigitated (400 $\mathrm{cm}^{2}$ loose) & $0.8 \times 0.8$ & $0.4-1.2-2.4$ & $10^{* *}$ & $\sim 751831$ & \\
\hline
\end{tabular}

* Stoich represents the ratio of input reactants molar versus the consumed one under certain current applied. ${ }^{* *}$ Units in $\left(\mathrm{mL} \mathrm{min}^{-1} \mathrm{~cm}^{-2}\right)$.

According to Ke et al. [110], further studies will be made about the flow field distributions as exploring new flow fields beyond the classic designs in order to reduce losses from kinetic, ohmic and mass transport for a better performance of the VRFB is desired.

\section{Conclusions}

A comprehensive review of VRFBs has been carried out in the present study. This is a very promising technological solution for large-scale stationary electric energy storage, due to their high cycle life, versatile design and independence between energy stored and rated power.

One of the key developments that VRFBs need for early commercialization-state is a deep study of different flow field distributions that are required in order to obtain a suitable balance between pressure losses and electrochemical reaction rate. The electrolyte homogeneous distribution and the pressure drop influence in order to get the less overpotential and the highest efficiency as possible is an essential factor when thinking about the stack configuration. Comparing different models at the same flow rate has to be remarked, as the 
behavior of the same pattern has important differences when studying it at different flow rates. Additionally, more research about new electrode materials are under development stage since most common materials such as graphite felts (GF) have poor low wettability properties with aqueous electrolytes. Therefore, a surface pretreatment is generally applied to achieve enough hydrophilic surface.

CFD based techniques have been proven as a useful tool to develop feasible numerical models for the optimization of energy systems based on redox flow technologies, which combined with rigorous experiments provide valuable information about the performance of the proposed flow field configurations. They allow to study several key parameters (flow rate, flow distribution through the channels and electrodes, pressure drop, charge-discharge states) to enhance the performance and lifetime of VRFBs.

A strong anticipated investment cost reduction for redox flow battery technologies means that by near future VRFBs have the potential to be the most cost-efficient energy storage system technology.

Author Contributions: Conceptualization, I.A. and U.F.-G.; methodology, A.M.-S.-V.; investigation, E.Z. and J.M.L.-G.; writing—original draft preparation, I.A., U.F.-G. and A.M.-S.-V.; writing-review and editing, J.M.L.-G.; supervision, J.M.L.-G.; project administration, I.A.; funding acquisition, E.Z. All authors have read and agreed to the published version of the manuscript.

Funding: The authors appreciate the support to the government of the Basque Country through research programs Grants N. ELKARTEK 20/71 and ELKARTEK 20/78.

Institutional Review Board Statement: Not applicable.

Informed Consent Statement: Not applicable.

Data Availability Statement: No new data were created or analyzed in this study. Data sharing is not applicable to this article.

Acknowledgments: The authors are grateful for the support provided by SGIker of UPV/EHU. This research has been developed under the frame of the Joint Research Laboratory on Offshore Renewable Energy (JRL-ORE).

Conflicts of Interest: The authors declare no conflict of interest.

\section{References}

1. Omer, A.M. Energy, environment and sustainable development. Renew. Sustain. Energy Rev. 2008, 12, 2265-2300. [CrossRef]

2. Gür, T.M. Review of electrical energy storage technologies, materials and systems: Challenges and prospects for large-scale grid storage. Energy Environ. Sci. 2018, 11, 2696-2767. [CrossRef]

3. Chiari, L.; Zecca, A. Constraints of fossil fuels depletion on global warming projections. Energy Policy 2011, 39, 5026-5034. [CrossRef]

4. Owusu, P.A.; Asumadu-Sarkodie, S. A review of renewable energy sources, sustainability issues and climate change mitigation. Cogent Eng. 2016, 3. [CrossRef]

5. Larcher, D.; Tarascon, J.-M. Towards greener and more sustainable batteries for electrical energy storage. Nat. Chem. 2015, 7, 19-29. [CrossRef] [PubMed]

6. Poullikkas, A. A comparative overview of large-scale battery systems for electricity storage. Renew. Sustain. Energy Rev. 2013, 27, 778-788. [CrossRef]

7. European Commission. Become Competitive in the Global Battery Sector to Drive E-Mobility Forward; Institute for Energy and Transport: Brussels, Belgium, 2016; pp. 1-10.

8. Rychcik, M.; Skyllas-Kazacos, M. Characteristics of a new all-vanadium redox flow battery. J. Power Sources 1988, $22,59-67$. [CrossRef]

9. Ulaganathan, M.; Aravindan, V.; Yan, Q.; Madhavi, S.; Skyllas-Kazacos, M.; Lim, T.M. Recent Advancements in All-Vanadium Redox Flow Batteries. Adv. Mater. Interfaces 2016, 3, 1500309. [CrossRef]

10. Lai, Q.; Zhang, H.; Li, X.; Zhang, L.; Cheng, Y. A novel single flow zinc-bromine battery with improved energy density. J. Power Sources 2013, 235, 1-4. [CrossRef]

11. Yang, J.H.; Yang, H.S.; Ra, H.W.; Shim, J.; Jeon, J.-D. Effect of a surface active agent on performance of zinc/bromine redox flow batteries: Improvement in current efficiency and system stability. J. Power Sources 2015, 275, 294-297. [CrossRef]

12. Hawthorne, K.L.; Petek, T.J.; Miller, M.A.; Wainright, J.S.; Savinell, R.F. An Investigation into Factors Affecting the Iron Plating Reaction for an All-Iron Flow Battery. J. Electrochem. Soc. 2015, 162, A108-A113. [CrossRef] 
13. Duduta, M.; Ho, B.; Wood, V.C.; Limthongkul, P.; Brunini, V.E.; Carter, W.C.; Chiang, Y.-M. Semi-Solid Lithium Rechargeable Flow Battery. Adv. Energy Mater. 2011, 1, 511-516. [CrossRef]

14. Lin, G.; Chong, P.Y.; Yarlagadda, V.; Nguyen, T.V.; Wycisk, R.J.; Pintauro, P.N.; Bates, M.; Mukerjee, S.; Tucker, M.C.; Weber, A.Z. Advanced Hydrogen-Bromine Flow Batteries with Improved Efficiency, Durability and Cost. J. Electrochem. Soc. 2016, 9 , A5049. [CrossRef]

15. Sum, E.; Skyllas-Kazacos, M. A study of the V(II)/V(III) redox couple for redox flow cell applications. J. Power Sources 1985, 15, 179-190. [CrossRef]

16. Sum, E.; Skyllas-Kazacos, M. A study of the V(V)/V(IV) system for use in the positive half-cell of a redox battery. J. Power Sources 1985, 16, 85-95. [CrossRef]

17. Cunha, Á.; Martins, J.; Rodrigues, N.; Brito, F.P. Vanadium redox flow batteries: A technology review. Int. J. Energy Res. 2014, 30, 889-918. [CrossRef]

18. Sánchez-Díez, E.; Ventosa, E.; Guarnieri, M.; Trovò, A.; Flox, C.; Marcilla, R.; Soavi, F.; Mazur, P.; Aranzabe, E.; Ferret, R. Redox flow batteries: Status and perspective towards sustainable stationary energy storage. J. Power Sources 2021, 481, 228804. [CrossRef]

19. Arribas, B.N.; Melício, R.; Teixeira, J.C.; Mendes, V.M.F. Vanadium Redox Flow Battery Storage System Linked to the Electric Grid. Renew. Energy Power Qual. J. 2016, 1025-1036. [CrossRef]

20. Zago, D.M.; Canzi, P. Analysis of flow field design for Vanadium Redox Flow Batteries through the development and validation of CFD codes. Appl. Energy 2018, 151. [CrossRef]

21. Arenas, L.F.; de Ponce León, C.; Walsh, F.C. Engineering aspects of the design, construction and performance of modular redox flow batteries for energy storage. J. Energy Storage 2017, 11, 119-153. [CrossRef]

22. Schmidt, O.; Melchior, S.; Hawkes, A.; Staffell, I. Projecting the Future Levelized Cost of Electricity Storage Technologies. Joule 2019, 3, 81-100. [CrossRef]

23. World Energy Council. E-Storage: Shifting from Cost to Value. Wind and Solar Applications; World Energy Council: London, UK, 2016; pp. 1-52. Available online: www.worldenergy.org (accessed on 12 September 2020).

24. World Energy Council. Energy Storage Monitor. Latest Trends in Energy Storage; World Energy Council: London, UK, $2019 ;$ pp. 1-32. Available online: www.worldenergy.org (accessed on 12 September 2020).

25. Tang, A.; McCann, J.; Bao, J.; Skyllas-Kazacos, M. Investigation of the effect of shunt current on battery efficiency and stack temperature in vanadium redox flow battery. J. Power Sources 2013, 242, 349-356. [CrossRef]

26. Mongird, K.; Viswanathan, V.V.; Balducci, P.J.; Alam, M.J.E.; Fotedar, V.; Koritarov, V.S.; Hadjerioua, B. Energy Storage Technology and Cost Characterization Report. 2019. PNNL-28866. Available online: https://energystorage.pnnl.gov/pdf/PNNL-28866.pdf (accessed on 18 September 2020).

27. Shibata, A.; Sato, K. Development of vanadium redox flow battery for electricity storage. Power Eng. J. 1999, 13, 130-135. [CrossRef]

28. International Energy Agency. Technology Mix in Storage Installations Excluding Pumped Hydro, 2011-2016. 2019. Available online: https: / / www.iea.org/data-and-statistics/charts/technology-mix-in-storage-installations-excluding-pumped-hydro2011-2016 (accessed on 2 September 2020).

29. Viswanathan, V.; Crawford, A.; Stephenson, D.; Kim, S.; Wang, W.; Li, B.; Coffey, G.; Thomsen, E.; Graff, G.; Balducci, P.; et al. Cost and performance model for redox flow batteries. J. Power Sources 2014, 247, 1040-1051. [CrossRef]

30. Zeng, Y.K.; Zhao, T.S.; An, L.; Zhou, X.L.; Wei, L. A comparative study of all-vanadium and iron-chromium redox flow batteries for large-scale energy storage. J. Power Sources 2015, 300, 438-443. [CrossRef]

31. Weber, A.Z.; Mench, M.M.; Meyers, J.P.; Ross, P.N.; Gostick, J.T.; Liu, Q. Redox flow batteries: A review. J. Appl. Electrochem. 2011, 41, 1137-1164. [CrossRef]

32. Ke, X.; Prahl, J.M.; Alexander, J.I.D.; Wainright, J.S.; Zawodzinski, T.A.; Savinell, R.F. Rechargeable redox flow batteries: Flow fields, stacks and design considerations. Chem. Soc. Rev. 2018, 47, 8721-8743. [CrossRef]

33. Esan, O.C.; Shi, X.; Pan, Z.; Huo, X.; An, L.; Zhao, T.S. Modeling and Simulation of Flow Batteries. Adv. Energy Mater. 2020, 2000758. [CrossRef]

34. Clemente, A.; Costa-Castelló, R. Redox Flow Batteries: A Literature Review Oriented to Automatic Control. Energies 2020, 13, 4514. [CrossRef]

35. Li, X.; Zhang, H.; Mai, Z.; Zhang, H.; Vankelecom, I. Ion exchange membranes for vanadium redox flow battery (VRB) applications. Energy Environ. Sci. 2011, 4, 1147. [CrossRef]

36. Derr, I.; Bruns, M.; Langner, J.; Fetyan, A.; Melke, J.; Roth, C. Degradation of all-vanadium redox flow batteries (VRFB) investigated by electrochemical impedance and X-ray photoelectron spectroscopy: Part 2 electrochemical degradation. J. Power Sources 2016, 325, 351-359. [CrossRef]

37. Knehr, K.W.; Kumbur, E.C. Open circuit voltage of vanadium redox flow batteries: Discrepancy between models and experiments. Electrochem. Commun. 2011, 13, 342-345. [CrossRef]

38. Zhang, H.; Li, X.; Zhang, J. Redox Flow Batteries; CRC Press, Taylor \& Francis Group: Boca Raton, FL, USA, 2018; ISBN 978-1-4987-5394-4.

39. Zhou, X.L.; Zhao, T.S.; An, L.; Wei, L.; Zhang, C. The use of polybenzimidazole membranes in vanadium redox flow batteries leading to increased coulombic efficiency and cycling performance. Electrochim. Acta 2015, 153, 492-498. [CrossRef] 
40. Yu, L.; Lin, F.; Xiao, W.; Xu, L.; Xi, J. Achieving efficient and inexpensive vanadium flow battery by combining CexZr1-xO2 electrocatalyst and hydrocarbon membrane. Chem. Eng. J. 2019, 356, 622-631. [CrossRef]

41. Chalamala, B.R.; Soundappan, T.; Fisher, G.R.; Anstey, M.R.; Viswanathan, V.V.; Perry, M.L. Redox Flow Batteries: An Engineering Perspective. Proc. IEEE 2014, 102, 976-999. [CrossRef]

42. Potash, R.A.; McKone, J.R.; Conte, S.; Abruña, H.D. On the Benefits of a Symmetric Redox Flow Battery. J. Electrochem. Soc. 2016, 163, A338-A344. [CrossRef]

43. Leung, P.; Shah, A.A.; Sanz, L.; Flox, C.; Morante, J.R.; Xu, Q.; Mohamed, M.R.; Ponce de León, C.; Walsh, F.C. Recent developments in organic redox flow batteries: A critical review. J. Power Sources 2017, 360, 243-283. [CrossRef]

44. Winsberg, J.; Hagemann, T.; Janoschka, T.; Hager, M.D.; Schubert, U.S. Redox-Flow Batteries: From Metals to Organic RedoxActive Materials. Angew. Chem. Int. Ed. 2017, 56, 686-711. [CrossRef]

45. Yang, Z.; Tong, L.; Tabor, D.P.; Beh, E.S.; Goulet, M.-A.; De Porcellinis, D.; Aspuru-Guzik, A.; Gordon, R.G.; Aziz, M.J. Alkaline Benzoquinone Aqueous Flow Battery for Large-Scale Storage of Electrical Energy. Adv. Energy Mater. 2018, 8, 1702056. [CrossRef]

46. Kwabi, D.G.; Lin, K.; Ji, Y.; Kerr, E.F.; Goulet, M.-A.; De Porcellinis, D.; Tabor, D.P.; Pollack, D.A.; Aspuru-Guzik, A.; Gordon, R.G.; et al. Alkaline Quinone Flow Battery with Long Lifetime at pH 12. Joule 2018, 2, 1894-1906. [CrossRef]

47. Liu, Y. A Long-Lifetime All-Organic Aqueous Flow Battery Utilizing TMAP-TEMPO Radical. Chem 2019, 5, 1861-1870. [CrossRef]

48. Choi, C.; Kim, S.; Kim, R.; Choi, Y.; Kim, S.; Jung, H.; Yang, J.H.; Kim, H.-T. A review of vanadium electrolytes for vanadium redox flow batteries. Renew. Sustain. Energy Rev. 2017, 69, 263-274. [CrossRef]

49. Skyllas-Kazacos, M.; McCann, J.F. Vanadium redox flow batteries (VRBs) for medium- and large-scale energy storage. In Advances in Batteries for Medium and Large-Scale Energy Storage; Elsevier: Amsterdam, The Netherlands, 2015; pp. 329-386. ISBN 978-1-78242-013-2.

50. Kim, K.J.; Park, M.-S.; Kim, Y.-J.; Kim, J.H.; Dou, S.X.; Skyllas-Kazacos, M. A technology review of electrodes and reaction mechanisms in vanadium redox flow batteries. J. Mater. Chem. A 2015, 3, 16913-16933. [CrossRef]

51. Castañeda, L.F.; Walsh, F.C.; Nava, J.L.; de Ponce León, C. Graphite felt as a versatile electrode material: Properties, reaction environment, performance and applications. Electrochim. Acta 2017, 258, 1115-1139. [CrossRef]

52. Leung, P.K. A mixed acid based vanadium-cerium redox flow battery with a zero-gap serpentine architecture. J. Power Sources 2015, 8, 651-658. [CrossRef]

53. Abbas, S.; Mehboob, S.; Shin, H.-J.; Han, O.H.; Ha, H.Y. Highly functionalized nanoporous thin carbon paper electrodes for high energy density of zero-gap vanadium redox flow battery. Chem. Eng. J. 2019, 378, 122190. [CrossRef]

54. He, Z.; Li, M.; Li, Y.; Li, C.; Yi, Z.; Zhu, J.; Dai, L.; Meng, W.; Zhou, H.; Wang, L. ZrO 2 nanoparticle embedded carbon nanofibers by electrospinning technique as advanced negative electrode materials for vanadium redox flow battery. Electrochim. Acta 2019, 309, 166-176. [CrossRef]

55. Jiang, Y.; Feng, X.; Cheng, G.; Li, Y.; Li, C.; He, Z.; Zhu, J.; Meng, W.; Zhou, H.; Dai, L.; et al. Electrocatalytic activity of MnO2 nanosheet array-decorated carbon paper as superior negative electrode for vanadium redox flow batteries. Electrochim. Acta 2019, 322, 134754. [CrossRef]

56. Wei, L.; Zhao, T.S.; Zeng, L.; Zeng, Y.K.; Jiang, H.R. Highly catalytic and stabilized titanium nitride nanowire array-decorated graphite felt electrodes for all vanadium redox flow batteries. J. Power Sources 2017, 341, 318-326. [CrossRef]

57. He, Z.; Li, M.; Li, Y.; Zhu, J.; Jiang, Y.; Meng, W.; Zhou, H.; Wang, L.; Dai, L. Flexible electrospun carbon nanofiber embedded with $\mathrm{TiO} 2$ as excellent negative electrode for vanadium redox flow battery. Electrochim. Acta 2018, 281, 601-610. [CrossRef]

58. He, Z.; Li, M.; Li, Y.; Wang, L.; Zhu, J.; Meng, W.; Li, C.; Zhou, H.; Dai, L. Electrospun nitrogen-doped carbon nanofiber as negative electrode for vanadium redox flow battery. Appl. Surf. Sci. 2019, 469, 423-430. [CrossRef]

59. Li, W.; Zhang, Z.; Tang, Y.; Bian, H.; Ng, T.; Zhang, W.; Lee, C. Graphene-Nanowall-Decorated Carbon Felt with Excellent Electrochemical Activity Toward $\mathrm{VO}_{2}{ }^{+} / \mathrm{VO}^{2+}$ Couple for All Vanadium Redox Flow Battery. Adv. Sci. 2016, 3, 1500276. [CrossRef] [PubMed]

60. Xia, L.; Zhang, Q.; Wu, C.; Liu, Y.; Ding, M.; Ye, J.; Cheng, Y.; Jia, C. Graphene coated carbon felt as a high-performance electrode for all vanadium redox flow batteries. Surf. Coat. Technol. 2019, 358, 153-158. [CrossRef]

61. He, Z.; Dai, L.; Liu, S.; Wang, L.; Li, C. $\mathrm{Mn}_{3} \mathrm{O}_{4}$ anchored on carbon nanotubes as an electrode reaction catalyst of V(IV)/V(V) couple for vanadium redox flow batteries. Electrochim. Acta 2015, 176, 1434-1440. [CrossRef]

62. Chang, Y.-C.; Chen, J.-Y.; Kabtamu, D.M.; Lin, G.-Y.; Hsu, N.-Y.; Chou, Y.-S.; Wei, H.-J.; Wang, C.-H. High efficiency of CO 2 -activated graphite felt as electrode for vanadium redox flow battery application. J. Power Sources 2017, 364, 1-8. [CrossRef]

63. Zhang, Z.H.; Zhao, T.S.; Bai, B.F.; Zeng, L.; Wei, L. A highly active biomass-derived electrode for all vanadium redox flow batteries. Electrochim. Acta 2017, 248, 197-205. [CrossRef]

64. Phillips, R.; Dunnill, C.W. Zero Gap Alkaline Electrolysis Cell Design for Renewable Energy Storage as Hydrogen Gas. RSC Adv. 2016, 6, 100643-100651. [CrossRef]

65. Eifert, L.; Banerjee, R.; Jusys, Z.; Zeis, R. Characterization of Carbon Felt Electrodes for Vanadium Redox Flow Batteries: Impact of Treatment Methods. J. Electrochem. Soc. 2018, 165, A2577-A2586. [CrossRef]

66. Lv, Y. Application of porous biomass carbon materials in vanadium redox flow battery. J. Colloid Interface Sci. 2020, 10, 434-443. [CrossRef]

67. Gencten, M.; Sahin, Y. A critical review on progress of the electrode materials of vanadium redox flow battery. Int. J. Energy Res. 2020, 44, 7903-7923. [CrossRef] 
68. Yang, S. Development and application of carbon fiber in batteries. Chem. Eng. J. 2020, 20. [CrossRef]

69. Trainham, J.A. A comparison between flow-through and flow-by porous electrodes for redox energy storage. Electrochim. Acta 1981, 26, 455-469. [CrossRef]

70. Reed, D.; Thomsen, E.; Wang, W.; Nie, Z.; Li, B.; Wei, X.; Koeppel, B.; Sprenkle, V. Performance of Nafion ${ }^{\circledR}$ N115, Nafion ${ }^{\circledR}$ NR-212, and Nafion ${ }^{\circledR}$ NR-211 in a $1 \mathrm{~kW}$ class all vanadium mixed acid redox flow battery. J. Power Sources 2015, 285, 425-430. [CrossRef]

71. Xu, Q.; Zhao, T.S.; Leung, P.K. Numerical investigations of flow field designs for vanadium redox flow batteries. Appl. Energy 2013, 105, 47-56. [CrossRef]

72. Reed, D.; Thomsen, E.; Li, B.; Wang, W.; Nie, Z.; Koeppel, B.; Kizewski, J.; Sprenkle, V. Stack Developments in a kW Class All Vanadium Mixed Acid Redox Flow Battery at the Pacific Northwest National Laboratory. J. Electrochem. Soc. 2016, 163, A5211-A5219. [CrossRef]

73. Gubler, L. Membranes and separators for redox flow batteries. Curr. Opin. Electrochem. 2019, 18, 31-36. [CrossRef]

74. Hu, B.; DeBruler, C.; Rhodes, Z.; Liu, T.L. Long-Cycling Aqueous Organic Redox Flow Battery (AORFB) toward Sustainable and Safe Energy Storage. J. Am. Chem. Soc. 2017, 139, 1207-1214. [CrossRef]

75. Li, Y.; Liu, Y.; Xu, Z.; Yang, Z. Poly(phenylene oxide)-Based Ion-Exchange Membranes for Aqueous Organic Redox Flow Battery. Ind. Eng. Chem. Res. 2019, 58, 10707-10712. [CrossRef]

76. Pezeshki, A.M.; Tang, Z.J.; Fujimoto, C.; Zawodzinski, T.A. Full Cell Study of Diels Alder Poly(phenylene) Anion and Cation Exchange Membranes in Vanadium Redox Flow Batteries. J. Electrochem. Soc. 2016, 10, A5154. [CrossRef]

77. Wang, K.; Chung, T. Fabrication of polybenzimidazole (PBI) nanofiltration hollow fiber membranes for removal of chromate. J. Membr. Sci. 2006, 281, 307-315. [CrossRef]

78. Hou, H.; Sun, G.; He, R.; Sun, B.; Jin, W.; Liu, H.; Xin, Q. Alkali doped polybenzimidazole membrane for alkaline direct methanol fuel cell. Int. J. Hydrogen Energy 2008, S036031990801152X. [CrossRef]

79. Shanahan, B.; Böhm, T.; Britton, B.; Holdcroft, S.; Zengerle, R.; Vierrath, S.; Thiele, S.; Breitwieser, M. $30 \mu \mathrm{m}$ thin hexamethyl-pterphenyl poly(benzimidazolium) anion exchange membrane for vanadium redox flow batteries. Electrochem. Commun. 2019, 102, 37-40. [CrossRef]

80. Wang, L.; Pingitore, A.T.; Xie, W.; Yang, Z.; Perry, M.L.; Benicewicz, B.C. Sulfonated PBI Gel Membranes for Redox Flow Batteries. J. Electrochem. Soc. 2019, 166, A1449-A1455. [CrossRef]

81. Shi, Y.; Eze, C.; Xiong, B.; He, W.; Zhang, H.; Lim, T.M.; Ukil, A.; Zhao, J. Recent development of membrane for vanadium redox flow battery applications: A review. Appl. Energy 2019, 238, 202-224. [CrossRef]

82. Schreiber, M.; Harrer, M.; Whitehead, A.; Bucsich, H.; Dragschitz, M.; Seifert, E.; Tymciw, P. Practical and commercial issues in the design and manufacture of vanadium flow batteries. J. Power Sources 2012, 206, 483-489. [CrossRef]

83. Kim, S.; Thomsen, E.; Xia, G.; Nie, Z.; Bao, J.; Recknagle, K.; Wang, W.; Viswanathan, V.; Luo, Q.; Wei, X.; et al. 1 kW/1 kWh advanced vanadium redox flow battery utilizing mixed acid electrolytes. J. Power Sources 2013, 237, 300-309. [CrossRef]

84. Bryans, D.; Amstutz, V.; Girault, H.H.; Berlouis, L.E.A. Characterisation of a 200 kW / 400 kWh Vanadium Redox Flow Battery. Batteries 2018, 4, 54. [CrossRef]

85. Guarnieri, M.; Trovò, A.; D'Anzi, A.; Alotto, P. Developing vanadium redox flow technology on a 9-kW 26-kWh industrial scale test facility: Design review and early experiments. Appl. Energy 2018, 230, 1425-1434. [CrossRef]

86. Trovò, A. Battery management system for industrial-scale vanadium redox flow batteries: Features and operation. J. Power Sources 2020, 465, 228229. [CrossRef]

87. Park, D.-J.; Jeon, K.-S.; Ryu, C.-H.; Hwang, G.-J. Performance of the all-vanadium redox flow battery stack. J. Ind. Eng. Chem. 2017, 45, 387-390. [CrossRef]

88. Wu, X.; Yuan, X.; Wang, Z.; Liu, J.; Hu, Y.; Deng, Q.; Yin, X.; Zhou, Q.; Zhou, W.; Wu, Y. Electrochemical performance of 5 $\mathrm{kW}$ all-vanadium redox flow battery stack with a flow frame of multi-distribution channels. J. Solid State Electrochem. 2017, 21, 429-435. [CrossRef]

89. Barton, J.L.; Brushett, F.R. A One-Dimensional Stack Model for Redox Flow Battery Analysis and Operation. Batteries 2019, 5, 25. [CrossRef]

90. Knudsen, E.; Albertus, P.; Cho, K.T.; Weber, A.Z.; Kojic, A. Flow simulation and analysis of high-power flow batteries. J. Power Sources 2015, 299, 617-628. [CrossRef]

91. Kumar, S.; Jayanti, S. Effect of electrode intrusion on pressure drop and electrochemical performance of an all-vanadium redox flow battery. J. Power Sources 2017, 360, 548-558. [CrossRef]

92. Sun, J.; Jiang, H.R.; Zhang, B.W.; Chao, C.Y.H.; Zhao, T.S. Towards uniform distributions of reactants via the aligned electrode design for vanadium redox flow batteries. Appl. Energy 2020, 259, 114198. [CrossRef]

93. Ozgoli, H.A.; Elyasi, S.; Mollazadeh, M. Hydrodynamic and electrochemical modeling of vanadium redox flow battery. Mech. Ind. 2015, 16, 201. [CrossRef]

94. Oh, K.; Yoo, H.; Ko, J.; Won, S.; Ju, H. Three-dimensional, transient, nonisothermal model of all-vanadium redox flow batteries. Energy 2015, 81, 3-14. [CrossRef]

95. Ma, X.; Zhang, H.; Xing, F. A three-dimensional model for negative half cell of the vanadium redox flow battery. Electrochim. Acta 2011, 58, 238-246. [CrossRef]

96. Wang, Y.; Cho, S.C. Analysis and Three-Dimensional Modeling of Vanadium Flow Batteries. J. Electrochem. Soc. 2014, 161, A1200-A1212. [CrossRef] 
97. Tang, A.; Bao, J.; Skyllas-Kazacos, M. Studies on pressure losses and flow rate optimization in vanadium redox flow battery. J. Power Sources 2014, 248, 154-162. [CrossRef]

98. Tsushima, S.; Suzuki, T. Modeling and Simulation of Vanadium Redox Flow Battery with Interdigitated Flow Field for Optimizing Electrode Architecture. J. Electrochem. Soc. 2020, 167, 020553. [CrossRef]

99. Aparicio-Mauricio, G.; Rodríguez, F.A.; Pijpers, J.J.H.; Cruz-Díaz, M.R.; Rivero, E.P. CFD modeling of residence time distribution and experimental validation in a redox flow battery using free and porous flow. J. Energy Storage 2020, 29, 101337. [CrossRef]

100. Dennison, C.R.; Agar, E.; Akuzum, B.; Kumbur, E.C. Enhancing Mass Transport in Redox Flow Batteries by Tailoring Flow Field and Electrode Design. J. Electrochem. Soc. 2016, 163, A5163. [CrossRef]

101. Messaggi, M.; Canzi, P.; Mereu, R.; Baricci, A.; Inzoli, F.; Casalegno, A.; Zago, M. Analysis of flow field design on vanadium redox flow battery performance: Development of 3D computational fluid dynamic model and experimental validation. Appl. Energy 2018, 228, 1057-1070. [CrossRef]

102. Yin, C.; Gao, Y.; Guo, S.; Tang, H. A coupled three dimensional model of vanadium redox flow battery for flow field designs. Energy 2014, 74, 886-895. [CrossRef]

103. Chen, J.Q.; Wang, B.G.; Lv, H.L. Numerical Simulation and Experiment on the Electrolyte Flow Distribution for All Vanadium Redox Flow Battery. Adv. Mater. Res. 2011, 236-238, 604-607. [CrossRef]

104. Jiang, H.R.; Sun, J.; Wei, L.; Wu, M.C.; Shyy, W.; Zhao, T.S. A high power density and long cycle life vanadium redox flow battery. Energy Storage Mater. 2020, 24, 529-540. [CrossRef]

105. Prumbohm, E.; Wehinger, G.D. Exploring Flow Characteristics in Vanadium Redox-Flow Batteries: Optical Measurements and CFD Simulations. Chem. Ing. Tech. 2019, 91, 900-906. [CrossRef]

106. Yaji, K.; Yamasaki, S.; Tsushima, S.; Suzuki, T.; Fujita, K. Topology optimization for the design of flow fields in a redox flow battery. Struct. Multidiscip. Optim. 2018, 57, 535-546. [CrossRef]

107. Ishitobi, H.; Saito, J.; Sugawara, S.; Oba, K.; Nakagawa, N. Visualized cell characteristics by a two-dimensional model of vanadium redox flow battery with interdigitated channel and thin active electrode. Electrochim. Acta 2019, 313, 513-522. [CrossRef]

108. Vynnycky, M. Analysis of a model for the operation of a vanadium redox battery. Energy 2011, 36, 2242-2256. [CrossRef]

109. Jyothi Latha, T.; Jayanti, S. Hydrodynamic analysis of flow fields for redox flow battery applications. J. Appl. Electrochem. 2014, 44, 995-1006. [CrossRef]

110. Ke, X.; Prahl, J.M.; Alexander, J.I.D.; Savinell, R.F. Redox flow batteries with serpentine flow fields: Distributions of electrolyte flow reactant penetration into the porous carbon electrodes and effects on performance. J. Power Sources 2018, 384, 295-302. [CrossRef]

111. Bortolin, S.; Toninelli, P.; Maggiolo, D.; Guarnieri, M.; Del Col, D. CFD study on electrolyte distribution in redox flow batteries. J. Phys. Conf. Ser. 2015, 655, 012049. [CrossRef]

112. Houser, J.; Clement, J.; Pezeshki, A.; Mench, M.M. Influence of architecture and material properties on vanadium redox flow battery performance. J. Power Sources 2016, 302, 369-377. [CrossRef] 